\title{
The Impact of Deforestation on Soil Conditions in Anambra State of Nigeria
}

\author{
Anyanwu J. C. ${ }^{1,}$, , Egbuche C. T. ${ }^{2}$, Amaku. G. E. ${ }^{1}$, Duruora J. O. ${ }^{3}$, Onwuagba, S. M. ${ }^{1}$ \\ ${ }^{1}$ Department of Environmental Technology, Federal University of Technology, Owerri, Nigeria \\ ${ }^{2}$ Department of Forestry and Wildlife Techhnology, Federal University of Technology, Owerri, Nigeria \\ ${ }^{3}$ Collage of Education, Nsugbe Anambra State, Nigeria
}

Email address:

jayjaychimezie@yahoo.com (Anyanwu J. C.)

\section{To cite this article:}

Anyanwu J. C., Egbuche C. T., Amaku. G. E., Duruora J. O., Onwuagba, S. M.. The Impact of Deforestation on Soil Conditions in Anambra State of Nigeria. Agriculture, Forestry and Fisheries. Special Issue: Environment and Applied Science Management in a Changing Global Climate. Vol. 4, No. 3-1, 2015, pp. 64-69. doi: 10.11648/j.aff.s.2015040301.21

\begin{abstract}
The research was carried out to determine the impact of deforestation on soil conditions in Anambra State. Ten soil samples were collected at random at a depth of $0-35 \mathrm{~cm}$ below the litter layer from forests and farmlands. The soil samples were collected and analyzed for $\mathrm{pH}$, field capacity, soil moisture, organic carbon, bulk density, soil micro-organism and particle size distribution. The result revealed that soil texture was mostly sandy except in some areas such as Atani, Nzam, Mmiata and Oroma-etiti, where it was generally heavy (clay loam). The result also revealed that the soil samples from the forests have better physical, chemical and biological properties compared to samples from farmlands. The results showed considerable variation for the soil physical, chemical and biological properties across the study area. Soil data were analyzed using Least Significant Difference (LSD). The analysis revealed that the main effect of land use was significant ( $\mathrm{p}<0.05$ ) for soil moisture, bulk density, organic carbon, organic matter, $\mathrm{pH}$, viable bacteria number and viable fungal propagule. It was not significant for sand, silt, clay and field capacity. The interaction effect of location and land use on soil properties were significant $(\mathrm{p}<0.05)$ only for soil moisture, it was not significant for other soil variables. The study recommended, among others, the protection of forests from deforestation so as to maintain good soil conditions in the study area.
\end{abstract}

Keywords: Soil Texture, Least Significant Difference, Soil Properties, Forests, Farmlands

\section{Introduction}

The aim of the study is to determine the extent to which deforestation affects soil conditions in Anambra state. Deforestation is the conversion of forested areas to non-forest land use such as arable land, urban use, wasteland or pasture. Anambra State is seriously threatened by deforestation. The 2006 national population and housing survey put the population of Anambra State at 4,182,032 and the population density at $863 / \mathrm{Km}^{2}$. The quest for more land to meet the needs of the rapidly expanding population in the state as well as the unfavorable economic downturn of many people is socio-economic drivers of deforestation in the state. This increase in population has reduced the fallow periods in the state, consequently little time is allowed for the soil to replenish its nutrients with the result that more forests are cleared for farmlands. The high rate, at which forests are currently converted to agriculture, indicates that the economic return from agriculture is higher than from forests, at least in the short term, and that the land is more valuable deforested than forested [1]. As population increases, the demand for wood continually increases. Trees are harvested for multiple uses ranging from lumber to wood for fuel. The rate of deforestation currently significantly exceeds the rate of forest renewal.

According to [2] when fallow periods are long enough to permit full vegetation regeneration and soil fertility restoration, this cultivation is recognized as ecologically balanced, economically attractive, and culturally integrated. It has been pointed out that certain woody species such as Dialium guineense, Anthonata macrophylla, Alchornea cordifolia, dominate the natural fallow system in the humid zone of southeastern Nigeria, where population density is high, the fallow period short, and the soil acid [3]; [4; [5]. Deforestation and cropping have caused a great deal of damage in Anambra State. This uncontrolled deforestation usually accompanied by poor soil management has led to 
land degradation and ecological imbalance in many parts of the state. Clearing and burning are deforestation methods employed by farmers and hunters in the state. The land clearing and post-clearing soil management methods employed in the state has affected the role of forests as carbon sequestration sites. Large scale deforestation in the state has also occurred as a result of construction works by the local, state and federal governments. Urbanization is another cause of deforestation in the state. The migration of people to urban areas has led to the clearing of forests for residential and other purposes. The citing of industries without recourse to the impact on the environment is also a problem in some parts of the state. Development initiatives such as road and building constructions are supplemented by growing encroachment and illegal logging has further increased the risk of deforestation in the state. The effects of deforestation include loss of soil nutrients, loss of valuable species of economic/medicinal value, siltation of rivers, species extinction, reduced biological diversity, reduced ecosystem stability, reduced plant biomass, and broken food chain. Increased rates of soil erosion have a potential of leading to a rise in river beds and hence increased frequency of flooding, threatening settlements and cultivable land. A major effect of deforestation in the state is increased soil erosion which has displaced people from their native homes, led to destruction of lives and property and collapse of infrastructural facilities in some parts of the state.

\section{Materials and Methods}

\subsection{Study Area}

This study was carried out in Anambra State of Southeastern Nigeria with the study sites located in four agro-ecological zones of the state established from the soil and vegetation maps modified from [6]. Anambra is a state in South-Eastern Nigeria. Its boundaries consist of Delta State to the west, Imo State to the south, Enugu State to the east and Kogi State to the north. The indigenous ethnic groups in Anambra State are the Igbo (98\% of population) and Igala (2\% of the population). Anambra State lies between Longitudes $6^{0} 35^{1} \mathrm{E}$ and $7^{0} 21^{1} \mathrm{E}$, and Latitudes $5^{0} 40^{1} \mathrm{~N}$ and $6^{0} 45^{1} \mathrm{~N}$. The climate is tropical with high annual rainfall ranging from $1,400 \mathrm{~mm}$ in the north to $2,500 \mathrm{~mm}$ in the south, with a mean monthly temperature of $27.6^{\circ} \mathrm{C}$. Heavy rainfall occurs within the months of April to October while the months of November to February have scanty rainfall, higher temperature and low humidity. Consequently, the natural vegetation in the greater part of the state is tropical dry or deciduous forest, which, in its original form, comprised tall trees with thick undergrowth and numerous climbers.

The four agro-ecological zones of the state were selected based on soil type characterized by vegetation. The soil was used as the basis for choosing the study sites because the soil is a more permanent feature than vegetation which is not stable and can be easily altered over time. The four zones consist of (A) Pale Brown Loamy Alluvial Soils characterized by Fresh Water Swamp Forest, (B) Dip Brown Red Soils Derived from Sandy Deposits characterized by Pennisetum-Dominated Grass Species, (C) Red and Brown Soils Derived from Sandstones and Shales characterized by Lowland Rain Forest, (D) Reddish Brown Gravelly and Pale Clayey Soils Derived from Shales which are characterized by Hyparrhenia-Dominated Grass species. Anambra State lies in the Anambra Basin, the first region where intensive oil exploration was carried out in Nigeria. The Anambra basin has about $6,000 \mathrm{~m}$ of sedimentary rocks [7]. The sedimentary rocks comprise ancient Cretaceous deltas, somewhat similar to the Niger Delta, with the Nkporo Shale, the Mamu Formation, the Ajali sandstone and the Nsukka formation as the main deposits. The soil types range from alluvial, hydromorphic and ferallitic soils. The alluvial soils are pale brown loamy soils and differ from the hydromorphic soils in being relatively immature and with its horizons not well developed. The alluvial soils are found in the two plain south of Onitsha and Ogbaru, and in the Niger Anambra low plain north of Onitsha. The alluvial soils sustain continuous cropping longer than the hydromorphic and ferallitic soils.

\subsection{Data Collection}

Relatively stable forests were identified from each of the agro-ecological zones. The forests served as control. Soil samples were collected randomly from each forest and from agricultural lands hundred meters away from the forests. The soil samples were collected for analysis of soil properties and examination of soil micro-organisms. Ten soil samples were collected at random, using soil auger at a depth zone of 0$35 \mathrm{~cm}$ below the litter layer from each agro-ecological zone. The soil samples were air-dried, gently crushed and made to pass through a $2 \mathrm{~mm}$ mesh. Plant residues, gravel and other foreign matter retained on the sieve were discarded [8]). Sieved samples were stored in unused polythene bags and labelled appropriately, before proceeding to the laboratory for analysis of selected soil properties.

\subsection{Determination of Parameters}

The following parameters were determined: Soil moisture, bulk density, particle size, soil $\mathrm{pH}$, organic carbon, organic matter, field capacity and microbial population. Morphological properties involved characterization of erosion sites. The moisture content of soil was determined by the gravimetric method in which wet soil was oven-dried at $105^{\circ} \mathrm{C}$ for 24 hours. It was expressed as a percentage of ovendry soil. Field capacity was measured by sampling the soil in the field after it had been thoroughly wetted to root zone depth by artificial irrigation. Small areas (about $1.50 \mathrm{~m}$ square) were selected from different locations. Each was surrounded by a raised bound and enough water was added to wet the upper $15 \mathrm{~cm}$ of the enclosed soil, the area being covered with polyethylene sheeting to prevent evaporation. The samples were collected at a depth of $0-35 \mathrm{~cm}$ and their moisture content determined [9]. The soil core method was used for the determination of bulk density in the field. 
Undisturbed soil core was excavated by a core sampler, the bulk density being calculated from the known volume of core and the weight of oven-dry soil. Before each test was performed, soil samples from each site were collected randomly. The samples were later bulked together in order to ensure adequate representation of each site. The bulking procedure for the soil samples was standardized by ensuring that samples collected were of equal volume. Particle size distribution was determined by the hydrometer method [11].

Textural classification was determined by the percentage of sand, silt and clay with the help of the US Department of Agriculture triangular diagram [12]. Soil $\mathrm{pH}$ was determined in soil-to-water ratio 1:2.5 with the help of a $\mathrm{pH}$ electrode and values were read out from $\mathrm{pH}$ meter [13]. Organic carbon was determined using Walkley and Black wet oxidation method. Organic matter was then calculated by a factor of 1.724 (Van Bemmelen's Correction Factor).

\subsection{Method of Data Analysis}

The data generated from the field studies were analyzed using relevant statistics. Two phases of statistical analysis were employed. First, whether the interaction and/or the main effects of location and land use were significant was analyzed. Second, treatment combinations having significant interactions and main effects were further compared.
Multiple comparisons of means were performed using Least Significant Difference (LSD) test. The Least Significant difference is used to compare means of different treatments that have an equal number of replications. The statistical procedures were performed using GenStat statistical package, GENSTAT Release 7.2 DE, Discovery Edition 3 [14].

\section{Results and Discussion}

The results of analysis of soil properties obtained from the field are shown below. The analysis helped to establish the impact of deforestation on soil conditions in the study area. Table 1 shows the Main Effect of Land use on soil properties. Table 2 presents the Interaction Effect of Location and Land use on the soil properties. The main effect of land use on soil properties is also presented in Figure 1. The results reveal that soil samples collected from farmlands had lower sand content than samples collected from forests in the study area. The difference in sand contents of farmlands and forests was, however, not significant. The silt and clay contents of soil from farmlands were higher than the silt and clay contents from forests. There were no significant differences between the silt content of farmlands and forests and between the clay contents of farmlands and forests.

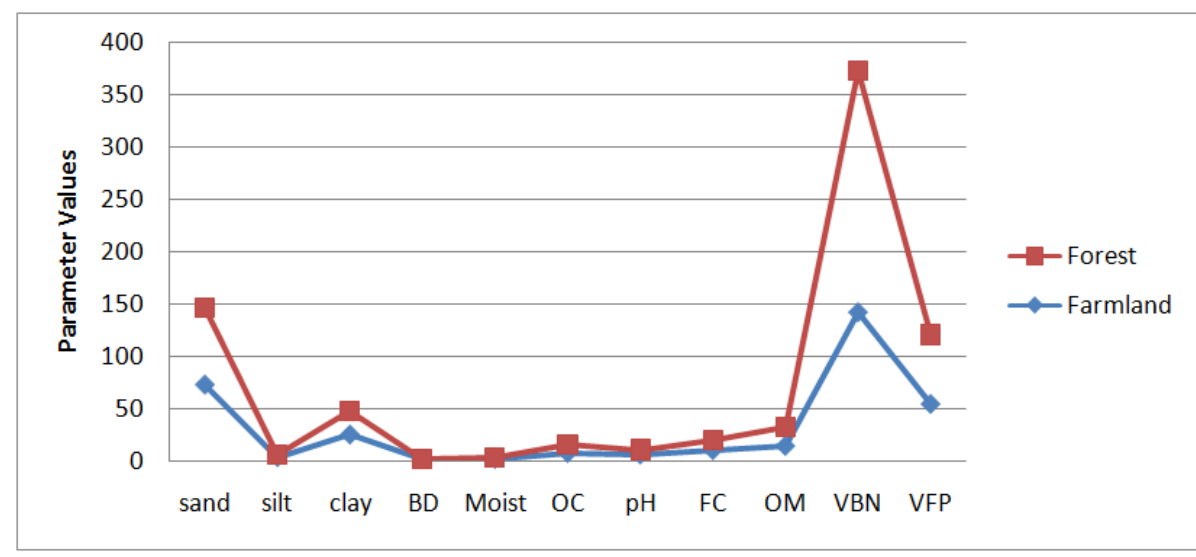

Figure 1. Soil Properties from Land Use in the Study Area

Table 1. Main Effect of Land Use on Soil Properties

\begin{tabular}{|c|c|c|c|c|c|c|c|c|c|c|c|}
\hline $\begin{array}{l}\text { Land } \\
\text { Use }\end{array}$ & $\begin{array}{l}\text { Sand } \\
\%\end{array}$ & Silt \% & $\begin{array}{l}\text { Clay } \\
\%\end{array}$ & $\begin{array}{l}\text { Bulk } \\
\text { Density } \\
\text { g/cm }\end{array}$ & $\begin{array}{l}\text { Moisture } \\
\%\end{array}$ & $\begin{array}{l}\text { Organic } \\
\text { Carbon } \\
\%\end{array}$ & pH & $\begin{array}{l}\text { Field } \\
\text { Capacity. \% }\end{array}$ & $\begin{array}{l}\text { Organic } \\
\text { Matter \% }\end{array}$ & $\begin{array}{l}\text { Viable } \\
\text { Bacteria } \\
\text { Number * } \\
10^{-3} \mathrm{~g} \\
\end{array}$ & $\begin{array}{l}\text { Viable } \\
\text { Fungal } \\
\text { Propagul } \\
\mathrm{e}^{*} 10^{-3} \mathrm{~g}\end{array}$ \\
\hline Farmland & 72.45 & 2.95 & 24.57 & 1.095 & 1.122 & 6.87 & 5.240 & 9.67 & 13.67 & 142.0 & 54.0 \\
\hline Forest & 73.88 & 2.71 & 23.32 & 0.875 & 1.455 & 9.20 & 5.891 & 9.68 & 18.41 & 231.0 & 66.7 \\
\hline $\mathrm{LSD}_{0.05}$ & NS & NS & NS & 0.973 & 0.2015 & 0.979 & NS & NS & 2.105 & 63.0 & 11.25 \\
\hline
\end{tabular}

Means differ significantly $(\mathrm{p}<5 \%$ ) as established by LSD-test NS $=$ Not Significant.

Source: Fieldwork, 2011

Table 1 further shows that soil samples collected from farmlands had significantly higher bulk density $\left(1.095 \mathrm{~g} / \mathrm{cm}^{3}\right)$ than samples collected from forests $\left(0.875 \mathrm{~g} / \mathrm{cm}^{3}\right)$. This is understandable because the soils of the farmlands have been exposed to erosion as a result of over cultivation which results in weaker consistence and thus higher bulk density. The lower bulk density of soil samples obtained from the forests is as a result of their better aggregation and higher consistence. This can be attributed to the fact that trees and other plants in the forest help to bind soil together thereby 
reducing erosion.

A very important significance of the bulk density of a soil is the amount of surface area a soil has. The higher the bulk density, the lower the surface area of the soil and these results in decreased capacity of the soil to retain water and nutrients. This implies that high bulk density is not desirable in agriculture. One effect of deforestation on soil condition in the study area is the increase in bulk density of the soil resulting in soil compaction, low soil nutrients and erosion. This finding agrees with the observations of [15].

The moisture content of soil from the forests $(1.455 \%)$ was significantly $(\mathrm{p}<0.05)$ higher than that of farmlands $(1.122 \%)$. The lower moisture content of soils from farmlands is an important effect of deforestation on soil conditions in the study area. The lower the soil moisture, the less able it can sustain vegetation. Deforestation affects the moisture content of the soil by exposing the soil to high solar radiation, which increases the rate of evaporation. Trees help to improve the porosity of the soil thereby retaining moisture. It is also important to note that soil moisture is an important mechanism in controlling the exchange of water and heat energy between the land surface and the atmosphere through evaporation and plant transpiration thus contributing to the development of weather patterns and the incidence of precipitation.

The differences in the organic carbon contents of the soil samples from forests and farmlands were equally significant $(p<0.05)$ with the forests having greater organic carbon content $(9.20 \%)$ than the farmlands $(6.87 \%)$. Soil organic carbon is derived from soil organic matter. Organic carbon therefore, is a measure of soil fertility and agricultural productivity potential. The lower organic carbon content of the soil from farmlands is an indication of loss of plant cover occasioned by deforestation and poor agricultural practices. This goes to show that clearing of forests for the purpose of agriculture, in the long run will have a negative effect on soil fertility and productivity. Organic carbon consists of amino acids, organic acids, plant fibers and the biomass of microorganisms. It drives the energy flow in soils, controls gaseous emissions and dictates the chemical and physical properties of the soil. One implication of this study, therefore, is that deforestation affects soil condition through the loss of soil fertility (i.e. reduced organic carbon content) in the study area. Similar finding has also been reported by [16].

The result further revealed that the $\mathrm{pH}$ of soil samples from farmlands was significantly lower (5.240) than for forests (5.891). The destruction of forest cover exposes the soil to erosion and contributes to soil acidification. It must be pointed out that if soil solution is too acidic, plants will not be able to utilize N, P, K and other nutrients they need. Also, plants are more likely to take up toxic metals and die eventually of toxicity. High soil acidity is therefore undesirable for plant growth. Based on the above findings, it can be implied that another effect of deforestation on soil condition in the study area is increased acidity of the soil. In their study, [17] revealed that soils in southeastern Nigeria are very acidic and of low fertility. The differences in field capacities of soils in forests and farmlands were not statistically significant (Table 1). Soil from farmland had field capacity value of $9.67 \%$, while soil from forest ecosystem had value of $9.68 \%$ which is a reflection of their water holding capacities. At field capacity, the water and air contents of the soil are considered to be ideal for crop growth.

Table 1 reveals that organic matter content of soil samples from forests $(18.41 \%)$ was significantly $(\mathrm{p}<0.05)$ higher than the organic matter content of samples collected from farmlands $(13.67 \%)$. This implies that soil samples from the forests were richer in organic matter when compared to soil samples from the farmlands. This is an indication that soil organic matter declines following deforestation and subsequent cultivation. This finding is in line with that of [18]. It was further observed that the color of most samples was dark, ranging from brown to black. The dark color is as a result of humus. The darker color of the forest soil layers compared to that of the farmlands is an indication that the forest harbors more organic matter in the soil and that loss of forest cover depletes the organic matter content of the soil. This is also an indication that the plough layer is affected by land preparation activities. It was also noted that the deeper the layers, the lighter the color, often grey, and sometimes mottled with yellowish or reddish spots. Soil organic matter directly benefits the soil microbial community and indirectly influences all other organisms, particularly plants. It is rich in nutrients such as nitrogen, phosphorous, sulfur, and micronutrients, and is comprised mostly of carbon. Vegetation generally helps to increase organic matter content of the soil. This is because tree and plant litters decay and are converted to organic matter in the soil thus enriching it. In the course of this study, it was also noticed that in order to amend and restore the soil fertility, most farmers resort to shifting cultivation, thereby causing further decline in forest cover in the state. Measures that can be adopted to increase organic matter in the study area include leaving residues on the soil surface, rotating crops with pasture or perennials, incorporating cover crops into crop rotation and by adding organic residues such as animal manure, litter or sewage sludge. This will no doubt help to reduce extensive agriculture which encourages deforestation.

The result further reveals that the soil microbial load of samples from forests were significantly $(p<0.05)$ higher when compared to that of samples from farmlands. The Viable Bacteria Number (VBN) for farmland was $142.0 * 10^{-3} \mathrm{~g}$ and $231.0^{*} 10^{-3} \mathrm{~g}$ for forest, while the Viable Fungal Propagule was $54.0 * 10^{-3} \mathrm{~g}$ for farmland and $66.7 * 10^{-3} \mathrm{~g}$ for forest. The preponderance of soil micro-organisms in the forests compared to the farmlands is an indication that the forests are more fertile than the farmlands and that when forests are cleared and converted to farmlands, there is usually loss of soil nutrients and poor soil condition. This is because nutrients tied up in organic matter are not readily available to plants; rather, microbes must first begin the decomposition process and obtain energy from organic carbon. As the organic matter is broken down, nutrients such as nitrogen and phosphorus are released into the soil and are then available 
for uptake by plants. The implication of this result is that deforestation reduces the soil microorganisms which replenish soil nutrients, thus leading to a decline in the soil nutrients available for plant growth.

Table 2 shows the interaction effect of location and land use on soil properties. The result shows that most of the soil variables were not significantly affected by the combined effect of location and land use. Only soil moisture contents of the farmlands and forests were significantly $(\mathrm{p}<0.05)$ affected.

Table 2. Interaction Effect of Location and Land Use on Soil Properties

\begin{tabular}{|c|c|c|c|c|c|c|c|c|c|c|c|c|}
\hline Location & Land Use & $\begin{array}{l}\text { Sand } \\
\%\end{array}$ & $\begin{array}{c}\text { Silt } \\
\%\end{array}$ & $\begin{array}{l}\text { Clay } \\
\%\end{array}$ & $\begin{array}{l}\text { Bulk D. } \\
\text { g/cm }\end{array}$ & $\begin{array}{l}\text { Moisture } \\
\%\end{array}$ & $\begin{array}{l}\text { OC } \\
\%\end{array}$ & pH & $\begin{array}{l}\text { Field C. } \\
\%\end{array}$ & $\begin{array}{l}\text { OM } \\
\%\end{array}$ & $\begin{array}{l}\mathrm{VBN} \\
* 10^{-3} \mathrm{~g} \\
\end{array}$ & $\begin{array}{l}\text { VFP } \\
* 10^{-}\end{array}$ \\
\hline A & Farmland & 55.65 & 4.30 & 40.05 & 0.914 & 1.632 & 7.88 & 6.182 & 11.15 & 14.36 & 194.0 & 65.6 \\
\hline A & Forest & 55.10 & 3.40 & 41.50 & 0.848 & 2.062 & 10.64 & 6.026 & 11.32 & 21.88 & 378.0 & 99.5 \\
\hline B & Farmland & 78.00 & 2.40 & 19.55 & 0.980 & 1.380 & 7.08 & 6.000 & 8.81 & 14.52 & 220.0 & 71.4 \\
\hline B & Forest & 80.25 & 2.33 & 17.10 & 0.894 & 2.192 & 9.84 & 5.946 & 9.08 & 19.98 & 334.0 & 87.7 \\
\hline $\mathrm{C}$ & Farmland & 76.85 & 2.55 & 20.60 & 0.967 & 0.630 & 6.26 & 5.042 & 8.86 & 13.36 & 81.0 & 50.3 \\
\hline $\mathrm{C}$ & Forest & 81.45 & 2.45 & 16.10 & 0.836 & 0.788 & 8.28 & 4.968 & 8.84 & 15.59 & 77.0 & 48.0 \\
\hline $\mathrm{D}$ & Farmland & 79.30 & 2.55 & 18.10 & 0.944 & 0.844 & 6.26 & 4.536 & 9.88 & 12.45 & 73.0 & 28.9 \\
\hline D & Forest & 78.71 & 2.65 & 18.60 & 0.920 & 0.778 & 8.02 & 4.622 & 9.49 & 16.19 & 135.0 & 31.7 \\
\hline $\mathrm{LSD}_{0.05}$ & & NS & NS & NS & NS & 0.4030 & NS & NS & NS & NS & NS & NS \\
\hline
\end{tabular}

Means differ significantly $(\mathrm{p}<5 \%)$ as established by LSD-test. Bulk D. = Bulk Density, OC $=$ organic carbon, FieldC. $=$ Field capacity, OM = Organic Matter, VBN $=$ Viable Bacterial Number, VFP $=$ Viable Fungal Propagule. NS $=$ Not Significant.

Source: Fieldwork, 2011

The above analysis revealed that the main effect of land use (Table 1) was significant $(\mathrm{p}<0.05)$ for soil moisture, bulk density, organic carbon, organic matter, $\mathrm{pH}$, viable bacteria number and viable fungal propagule. It was not significant for sand, silt, clay and field capacity. This implies that not all the soil properties were affected by the land use (forest or farmland). In essence, it means that deforestation affects certain soil properties more than others. The interaction effect of location and land use on soil properties (Table 2) were significant $(\mathrm{p}<0.05)$ only for soil moisture, which goes to show that deforestation not only affects the moisture content of the soil, but that soil moisture is essential for vegetation regeneration and sustenance. It was not significant for other soil variables, which means that the interaction of location and land use on soil properties did not affect most of the soil properties significantly.

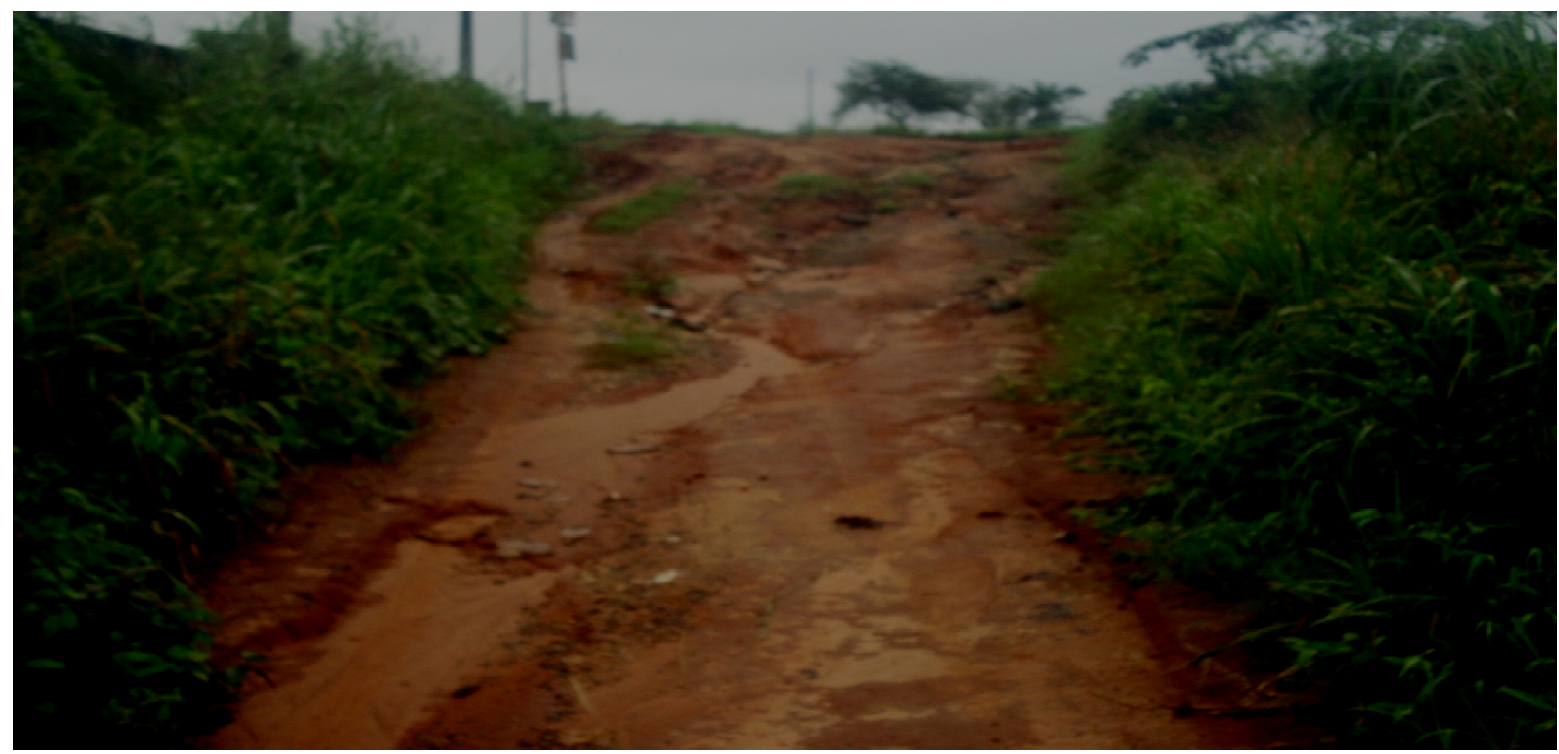

Figure 2. Soil degradation in Oba, Anambra State, Nigeria

\section{Conclusion}

The study observed that degradation of the soil as a result of deforestation leads to poor soil physical, chemical and biological conditions which are a function of the soil properties. Therefore, protection of forests from deforestation will help to maintain good soil conditions in the study area.

Forest degradation is demographically driven. This is one manifestation of population explosion. There is need to inform and educate the people about links between forest preservation and the need to control population growth. To 
curb deforestation in Anambra State, policy makers at all levels should begin to see the need for new conservation strategies. The traditional approach of restricting access to isolated forests in areas designated as parks and then employing park guards to protect the forests may not achieve the desired goal, rather modern strategies which should take into consideration the needs of the poor masses living in and near the forests should be adopted as well. The local people should be carried along when planning any conservation strategy. This is because no effective conservation can be achieved without the cooperation of the local people.

The realization of the fact that deforestation can have negative impact leading to poor soil productivity, climate change, erosion, flooding, loss of lives and property, and loss of biodiversity, led to the need for this study in Anambra State. The study suggested ways to mitigate the environmental problems associated with deforestation in the state. It revealed the impact of deforestation on soil conditions in the state. This is in view of the fact that soil degradation is a serious problem that can lead to loss of soil fertility which in turn will affect crop production and productivity with its resultant food insecurity in the state.

\section{References}

[1] Gaston, G., Brown, S., Lorenzini, M., and Singh, K. D. (1998) State and change in carbon pools in the forests of tropical Africa. Global Change Biology, Vol. 4, pp. 97-114

[2] Raintree, J.B., and Warner, K. (1986). Agrofor. Syst. 4, 39-54.

[3] Obi, J.L., and Tuley, P. (1973). The Bush Fallow and Ley Farming in the Oil Palm Belt of Southeastern Nigeria. Land Resour. Div. Misc. Rep. No. 161. ODM., England.

[4] Okigbo, B.N. (1982). In "Agroforestry in the African Humid Tropics" (L. H. Macdonald, ed.), pp.41-45. United Nations Univ., Tokyo.

[5] Getahun, A., Wilson, G.F., and Kang, B. T. (1982). In "Agroforestry in the African Humid Tropics" (H. McDonald, eds.), pp.28-36. United Nations Univ., Tokyo.

[6] Ofomata, G.E.K. (1975). Nigeria in Maps: Eastern States. In G.E.K. Ofomata (Ed). Vegetation Types and Soils. pp.30-45.
Ethiope Publishing House,Benin, Nigeria.

[7] Olusola, J. O., Ajibola, U. K., and Samuel O. A. (2003). Depositional Environments, Organic Richness, and Petroleum Generating Potential of the Campanian to Mastrichtian Enugu Formation, Anambra Basin,Nigeria.

[8] Kundu, N.K. and Ghose, M.K. (1997). Studies on the topsoil of an opencast coal mine. Environmental Conservation, 21 (2), 126-132.

[9] Kundu, N.K. and Ghose, M.K. (1997). Studies on the topsoil of an opencast coal mine. Environmental Conservation, 21 (2), 126-132.

[10] Dakshinamurti, C. and Gupta, R.P. (1968). Practicals in Soil Physics, pp. 1-16. Indian Agricultural Research Institute, New Delhi.

[11] Gee, G.W. and Bauder, J.W. (1986) Particles size analysis. In: Methods of Soil analysis part 1. A. Klute (Eds) Am. Soc. Agron. Madision 101 USA. pp. 38 - 41.

[12] Biswas, T.D. and Mukherjee, S.K. (1994). Textbook of Soil Science. Tata McGraw Hill Publishing Co. Ltd., second reprint, New Delhi.

[13] Ghose, A.B., Bajaj, J.C., Hasan, R. and Singh, D. (1983). Soil and Water Testing Methods. Indian Agricultural Research Institute, New Delhi.

[14] Genstat 5 Reference Manual, Clarendon Press, Oxford 1987, 749 pp., ISBN 0-19-852212-6

[15] Ogbodo, E.N., Okorie, P.O. and Utobo, E. B. (2010). Growth and Yield of Lettuce (Lactuca sativa L.) at Abakaliki AgroEcological Zone of Southeastern Nigeria. World Journal of Agricultural Sciences. Vol 6, No 2, pp. 144-148.

[16] Asadu C. L. A. and Akamigbo F.O.R. (1990). Relative contribution of organic matter and clay fractions to cation exchange capacity of soils in southeastern Nigeria. Samaru. J. Agri. Res. Vol 7, pp 17-23

[17] Asadu C. L. A. and Akamigbo F.O.R. (1990). Relative contribution of organic matter and clay fractions to cation exchange capacity of soils in southeastern Nigeria. Samaru. J. Agri. Res. Vol 7, pp 17-23.

[18] Lemenih, M., Karltun, E., and Tolera, M. (2011). Comparing farmers' perception of soil fertility change with soil properties and crop performance in Beseku, Ethiopia. Land Degraded. Development. 